\title{
DISTRIBUSI, EKOLOGI, DAN STATUS KONSERVASI Hernandia nymphaeifolia (C. PresI) Kubitzki DI KALIMANTAN
}

\section{Distribution, ecology, and conservation status of Hernandia nymphaeifolia (C. Presl) Kubitzki in Kalimantan}

\author{
Bina Swasta Sitepu*, Tri Atmoko \\ Balai Penelitian dan Pengembangan Teknologi Konservasi Sumber Daya Alam, \\ Kementerian Lingkungan Hidup dan Kehutanan \\ Jl. Soekarno Hatta Km. 38, Sungai Merdeka, Samboja Kutai Kartanegara, Kalimantan Timur 72127 \\ *Email: binassitepu@gmail.com
}

Diterima/Received: 10 Maret 2020; Disetujui/Accepted: 9 Juli 2020

\begin{abstract}
Research on distribution, habitat, and conservation status of Hernandia nymphaeifolia (C. Presl.) Kubitzki growing on sandy coastal forests were conducted in Kalimantan, Indonesia. The study showed that $H$. nymphaeifolia were distributed in all regions of Kalimantan, but not always found in their habitat. Species of plants dominated the habitat vegetation were Calophyllum inophyllum, Hibiscus tiliaceus and Pongamia pinnata. Soil characteristic in the habitat was dominated with sandy structure with low nutrition content. Seven populations and 44 mature trees were found in Kalimantan. An assessment of the conservation status of $H$. nymphaeifolia following IUCN guideline criteria showed that its status in Indonesia was Endangered (EN B2b(ii,iii)c(ii, iii).
\end{abstract}

Keywords: conservation status, endangered, Hernandia nymphaeifolia, IUCN criteria, Kalimantan

\begin{abstract}
Abstrak
Penelitian distribusi, habitat, dan status konservasi Hernandia nympaheifolia (C. Presl) Kubitzki dilakukan di seluruh wilayah Kalimantan, Indonesia, khususnya pada habitat hutan pantai berpasir. Hasil penelitian menunjukkan jenis ini hidup tersebar di seluruh wilayah Kalimantan, namun tidak selalu ditemukan pada habitat hutan pantai berpasir. Jenis-jenis dominan pembentuk habitat H. nympaheifolia adalah Calophyllum inophyllum, Hibiscus tiliaceus, dan Pongamia pinnata. Tipe tanah pada habitat adalah dominan pasir dengan tingkat kesuburan yang rendah. Berdasarkan hasil survei ditemukan tujuh jumlah populasi dan 44 pohon dewasa di Kalimantan. Status konservasi $H$. nympaheifolia di Indonesia berdasarkan kriteria IUCN termasuk genting /EN (B2b(ii, iii)c(ii,iii).
\end{abstract}

Kata kunci: genting, Hernandia nymphaeifolia, Kalimantan, kriteria IUCN, status konservasi

\section{PENDAHULUAN}

Hernandia nymphaeifolia (C. Presl) Kubitzki merupakan salah satu jenis dari suku Hernandiaceae dengan sebaran alami di daerah pantai berpasir, mulai dari Kenya, Tanzania, Madagaskar, Kepulauan Christmas di Samudra Hindia, Sumatra, Jawa, Sulawesi, hingga Kepulauan Solomon (Duyfjes 1993; Irwanto 1998; Turner et al. 2000; Michalak et al. 2010; Kalima 2013; Alfaida et al. 2013; POWO 2019). Perawakan jenis ini berupa pohon besar dengan diameter mencapai $50 \mathrm{~cm}$ dan tinggi $20 \mathrm{~m}$. Daun tunggal, peltate, berbentuk bulat telur dengan kedua sisi licin agak mengkilap. Buah $H$. nymphaeifolia berbentuk lentera atau lampion berwarna kehijauan hingga merah muda dengan satu biji berwarna hitam (Irwanto 1998). Di Indonesia, pohon ini dikenal dengan nama kampis (Sunda), bengkak (Jawa), nyalako (Ternate), dan nyalau (Tidore) (Heyne 1987). 
H. nymphaeifolia memiliki kayu yang ringan dan mudah dikerjakan, sangat baik untuk perabotan rumah tangga dan kegunaan lain yang bersifat konstruksi ringan (Irwanto 1998). Namun kayu ini kurang benilai secara ekonomis kecuali untuk keperluan lokal karena tidak awet dan jarang ditemukan dalam jumlah yang banyak. Secara tradisional, kulit batang, dahan, dan daunnya digunakan untuk pengobatan malaria, demam, keracunan, dan pereda rasa sakit (Dittmar 1991; Lakshmi et al. 2009; Arini \& Kinho 2015). Penelitian terkini juga mengungkap berbagai jenis senyawa kimia dari bagian-bagian tumbuhannya yang berpotensi sebagai obat kanker dan tumor (Suthiwong et al. 2018; Aimaiti et al. 2019), pereda nyeri dan mengurangi peradangan (Das et al. 2013; Wei et al. 2018). Jenis ini juga memiliki kandungan lemak pada bagian biji yang berpotensi sebagai bahan baku campuran biodiesel (Duyfjes 1996), namun hingga kini belum ada penelitian yang membuktikannya.

H. nymphaeifolia memiliki daerah sebaran yang luas, yaitu sepanjang pantai yang berpasir di daerah tropis, namun keberadaannya kini cenderung semakin berkurang sebagai akibat dari konversi habitat dalam bentuk pemanfaatan dan kerusakan secara alami akibat abrasi. Jenis ini termasuk dalam kategori Genting (Endangered) bersama Lumnitzera littorea (Jack) Voigt dan Pemphis acidula J.R. Forst. \& G. Forst. di China akibat pemanfaatan yang tidak terkendali (Zhong et al. 2011). Secara global dan Indonesia, jenis ini belum dinilai kategori kelangkaannya karena persebarannya yang pantropical (seluruh daerah tropis). Selain itu, ekosistem hutan pantai berpasir sebagai habitat jenis ini juga rentan terhadap kerusakan akibat pemanfaatan oleh manusia (Giri et al. 2015; Pinto 2015), maupun akibat alami seperti erosi, tsunami, dan gempa bumi (Tuheteru \& Mahfudz 2012; Jonah et al. 2016; Prihantono et al. 2018; Suyarso et al. 2018).

Aspek ekologi dan populasi $H$. nymphaeifolia telah dipublikasikan oleh Sitepu (2015). Namun demikian, informasi tersebut perlu diperbaharui untuk mengisi kekosongan (gap) informasi untuk digunakan sebagai dasar penentuan status konservasi dan dan pemanfaatan jenis ini.

\section{METODE}

\section{Lokasi dan waktu}

Dua puluh tiga kawasan pesisir pantai berpasir pada empat provinsi di Kalimantan (Tabel 1, Gambar 1) yang diketahui merupakan habitat alami $H$. nymphaeifolia dijadikan sebagai lokasi pengambilan data pada tahun 2012-2016. Penelusuran informasi awal tentang lokasi dan habitat dilakukan dengan penelusuran terhadap penelitian terdahulu maupun informasi dari spesimen di Herbarium Wanariset (WAN). Data di Provinsi Kalimantan Utara belum dapat diambil karena adanya keterbatasan waktu dan sumber daya, namun pengamatan cepat di pantai Amal, Kota Tarakan tidak menemukan tegakan H. nymphaeifolia. Tambahan informasi populasi didapatkan dari kegiatan eksplorasi herbarium WAN pada tahun 2018 di Pantai Biduk-Biduk, Berau.

\section{Cara kerja}

Bahan penelitian yang digunakan adalah seluruh tegakan $H$. nymphaeifolia dan jenis tumbuhan lain yang ditemukan, serta contoh tanah di lokasi penelitian. Untuk memperoleh data dan informasi secara rinci berkaitan dengan aspek distribusi, populasi, dan ekologi habitat H. nymphaeifolia (kecuali curah hujan), dilakukan penjelajahan di sepanjang pantai berpasir di setiap lokasi penelitian. Jika ditemukan jenis H. nymphaeifolia diambil data koordinatnya. Data sebaran juga berdasarkan data koordinat sebaran koleksi spesimen di Herbarium WAN khusus di Kalimantan. Data koordinat sebaran ditabulasi dan dipetakan menggunakan program ArcGIS 10.1 (ESRI 2012). Setiap lokasi ditemukan jenis ini diambil juga koleksi herbariumnya dan disimpan di WAN sebagai bukti otentik keberadaan dan distribusinya. 


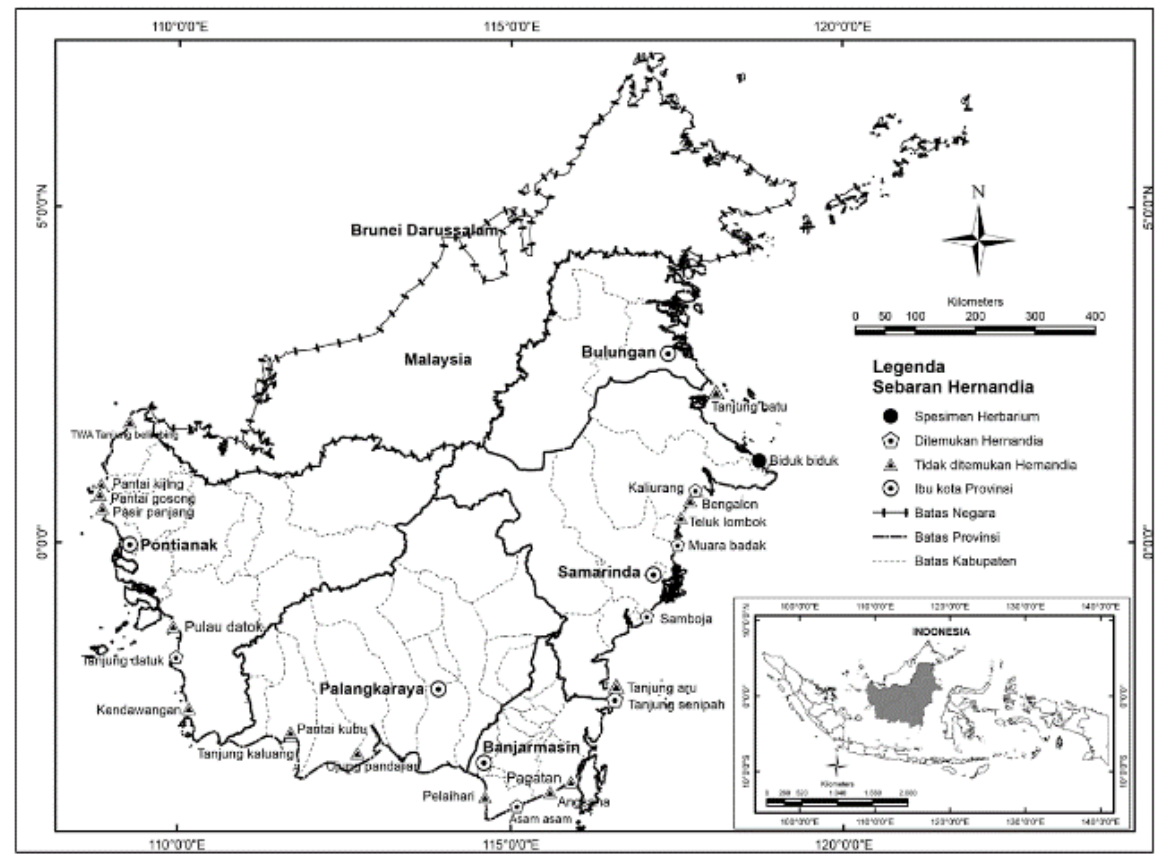

Gambar 1. Peta sebaran H. nymphaefolia di Kalimantan

Tabel 1. Lokasi penelitian H. nymphaeifolia di Kalimantan

\begin{tabular}{|c|c|c|c|c|c|c|}
\hline \multirow{2}{*}{ No. } & \multirow{2}{*}{ Provinsi } & \multirow{2}{*}{ Kabupaten } & \multirow{2}{*}{ Lokasi } & \multirow{2}{*}{$\begin{array}{c}\text { Panjang } \\
\text { jalur } \\
(\mathrm{km})\end{array}$} & \multicolumn{2}{|c|}{ Koordinat geografis } \\
\hline & & & & & Latitude & Logitude \\
\hline \multirow[t]{2}{*}{1} & Kalimantan Barat & Sambas & Tanjung & 8,96 & $1^{\circ} 47^{\prime} 24^{\prime \prime} \mathrm{N}$ & $109^{\circ} 18^{\prime} 04^{\prime \prime} \mathrm{E}$ \\
\hline & & & Belimbing & & & \\
\hline 2 & & Bengkayang & Pantai Gosong & 2,30 & $0^{\circ} 42^{\prime} 39^{\prime \prime} \mathrm{N}$ & $108^{\circ} 52^{\prime} 24^{\prime \prime} \mathrm{E}$ \\
\hline 3 & & & Pasir Panjang & 7,29 & $0^{\circ} 50^{\prime} 56^{\prime \prime} \mathrm{N}$ & $108^{\circ} 52^{\prime} 59^{\prime \prime} \mathrm{E}$ \\
\hline 4 & & Mempawah & Pantai Kijing & 1,28 & $0^{\circ} 30^{\prime} 24^{\prime \prime} \mathrm{N}$ & $108^{\circ} 54^{\prime} 30^{\prime \prime} \mathrm{E}$ \\
\hline 5 & & Ketapang & Tanjung Datuk ${ }^{1}$ & 11,80 & $2^{\circ} 11^{\prime} 32^{\prime \prime} \mathrm{S}$ & $110^{\circ} 05^{\prime} 12^{\prime \prime} \mathrm{E}$ \\
\hline \multirow[t]{2}{*}{6} & & & Tanjung & 5,17 & $1^{\circ} 43^{\prime} 17^{\prime \prime} \mathrm{S}$ & $109^{\circ} 59^{\prime} 42^{\prime \prime} \mathrm{E}$ \\
\hline & & & Belandang & & & \\
\hline 7 & & Kayong Utara & Pulau Datok & 1,39 & $1^{\circ} 15^{\prime} 45^{\prime \prime} \mathrm{S}$ & $109^{\circ} 57^{\prime} 26^{\prime \prime} \mathrm{E}$ \\
\hline 8 & Kalimantan Tengah & Kotawaringin & Tanjung Kaluang & 4,39 & $2^{\circ} 54^{\prime} 21^{\prime \prime} \mathrm{S}$ & $111^{\circ} 42^{\prime} 22^{\prime \prime} \mathrm{E}$ \\
\hline 9 & & Timur & Pantai Kubu & 10,83 & $2^{\circ} 56^{\prime} 55^{\prime \prime} \mathrm{S}$ & $111^{\circ} 39^{\prime} 21^{\prime}$ 'E \\
\hline 10 & & $\begin{array}{l}\text { Kotawaringin } \\
\text { Barat }\end{array}$ & Ujung Pandaran & 45,57 & $3^{\circ} 10^{\prime} 32^{\prime \prime} \mathrm{s}$ & $112^{\circ} 59^{\prime} 31^{\prime \prime} \mathrm{E}$ \\
\hline 11 & Kalimantan Selatan & Tanah Bumbu & Asam-Asam ${ }^{1}$ & 6,61 & $3^{\circ} 58^{\prime} 40^{\prime \prime} \mathrm{S}$ & $115^{\circ} 05^{\prime} 17^{\prime \prime} \mathrm{E}$ \\
\hline 12 & & & Pagatan & 8,62 & $3^{\circ} 36^{\prime} 47^{\prime \prime} \mathrm{S}$ & $115^{\circ} 54^{\prime} 57^{\prime \prime} \mathrm{E}$ \\
\hline 13 & & & Angsana & 2,38 & $3^{\circ} 45^{\prime} 13^{\prime \prime} \mathrm{S}$ & $115^{\circ} 37^{\prime} 45^{\prime \prime} \mathrm{E}$ \\
\hline 14 & & Tanah Laut & Pelaihari & 11,05 & $3^{\circ} 52^{\prime} 55^{\prime \prime} \mathrm{s}$ & $114^{\circ} 36^{\prime} 38^{\prime \prime} \mathrm{E}$ \\
\hline 15 & Kalimantan Timur & Kutai & Samboja ${ }^{1}$ & 5,92 & $1^{\circ} 07^{\prime} 28^{\prime \prime} \mathrm{S}$ & $117^{\circ} 02^{\prime} 28^{\prime \prime} \mathrm{E}$ \\
\hline 16 & & Kartanegara & Muara Badak ${ }^{1}$ & 3,79 & $0^{\circ} 02^{\prime} 53^{\prime \prime} \mathrm{S}$ & $117^{\circ} 30^{\prime} 20^{\prime \prime} \mathrm{E}$ \\
\hline 17 & & Paser & Tanjung Senipah ${ }^{1}$ & 2,70 & $2^{\circ} 22^{\prime} 27^{\prime \prime} \mathrm{S}$ & $116^{\circ} 33^{\prime} 49^{\prime \prime} \mathrm{E}$ \\
\hline 18 & & & Tanjung Aru & 4,55 & $2^{\circ} 10^{\prime} 20^{\prime \prime} \mathrm{S}$ & $116^{\circ} 35^{\prime} 08^{\prime \prime} \mathrm{E}$ \\
\hline 19 & & Berau & Tanjung Batu & 4,21 & $2^{\circ} 05^{\prime} 08^{\prime \prime} \mathrm{N}$ & $117^{\circ} 50^{\prime} 01^{\prime \prime} \mathrm{E}$ \\
\hline 20 & & & Biduk-Biduk $^{1}$ & - & $1^{\circ} 13^{\prime} 11^{\prime \prime} \mathrm{N}$ & $118^{\circ} 41^{\prime} 14^{\prime \prime} \mathrm{E}$ \\
\hline 21 & & Kutai Timur & Bengalon & 4,63 & $0^{\circ} 46^{\prime} 53^{\prime \prime} \mathrm{N}$ & $117^{\circ} 47^{\prime} 22^{\prime \prime} \mathrm{E}$ \\
\hline 22 & & & Kali Urang ${ }^{1}$ & 6,41 & $0^{\circ} 47^{\prime} 50^{\prime \prime} \mathrm{S}$ & $117^{\circ} 48^{\prime} 40^{\prime \prime} \mathrm{E}$ \\
\hline 23 & & & Teluk lombok & 8,62 & $0^{\circ} 21^{\prime} 57^{\prime \prime} \mathrm{s}$ & $117^{\circ} 33^{\prime} 18^{\prime \prime} \mathrm{E}$ \\
\hline
\end{tabular}

1) Lokasi ditemukan tegakan H. nymphaeifolia

Sumber: Sitepu (2015), data primer 
Pada lokasi ditemukan tegakan H. nympahefolia dibuat petak pengamatan kuadrat berukuran 10x10 m untuk pengamatan aspek keragaman vegetasi dan ekologi (Susilo 2017), kecuali di Muara Asam-Asam (Kalimantan Selatan) dan Samboja (Kalimantan Timur) yang masingmasing hanya ditemukan satu dan dua pohon $H$. nymphaeifolia tanpa ada vegetasi lainnya dalam jarak $20 \mathrm{~m}$ dari batang utama. Semua pohon dengan batang berdiameter $\geq 10 \mathrm{~cm}$ di dalam petak diidentifikasi nama ilmiahnya dan dicatat data diameter batang dan tinggi. Pendataan terhadap pancang dan semai $H$. nymphaeifolia dilakukan juga pada petak 10×10 m untuk menghindari hilangnya data permudaan tumbuhan dalam pengamatan. Kriteria semai adalah individu tumbuhan dengan tinggi kurang dari 1,5 $\mathrm{m}$ dan kriteria pancang berupa individu tumbuhan dengan tinggi lebih dari 1,5 m dan diameter kurang dari $10 \mathrm{~cm}$.

Pengambilan contoh tanah berikut data $\mathrm{pH}$ dan kelembapannya dilakukan pada setiap petak untuk menggambarkan kondisi tanah yang sesungguhnya saat penelitian dilakukan. Pengambilan contoh tanah meliputi lapisan atas tanah hingga kedalaman $30 \mathrm{~cm}$. Pada lokasi tertentu tidak dapat dibuat petak pengamatan vegetasi, karena ketiadaan vegetasi lain selain $H$. nymphaeifolia, pengambilan contoh tanah dilakukan dalam radius $1 \mathrm{~m}$ dari batang utama. Analisis tanah dilakukan berdasarkan sampel yang diambil per provinsi, dengan mempertimbangkan kondisi habitat yang serupa di seluruh lokasi yaitu pantai berpasir. Analisis sampel tanah dilakukan di Laboratorium Tanah PUSREHUT, Universitas Mulawarman.

Populasi $H$. nymphaeifolia dihitung dengan metode sensus berdasarkan pertemuan di lapangan di seluruh lokasi penelitian dengan pertimbangan jumlah individu yang tidak banyak di setiap lokasi penelitian (Elzinga et al. 1998). Habitat alami $H$. nymphaeifolia berupa ekosistem pantai berpasir memudahkan dalam pencarian dan penghitungan jenis ini di lapangan, dan memberikan batasan wilayah jelajah yang jelas. Penghitungan populasi didasarkan pada bentang wilayah (landscape) dan jumlah individu dewasa didasarkan pada ukuran diameter minimal $10 \mathrm{~cm}$ dan atau telah berbunga/berbuah.

\section{Analisis data}

Aspek ekologi yang berkaitan dengan vegetasi, terutama komposisi, kerapatan, dan jenis yang dominan dihitung indeks nilai penting (INP) dari setiap jenis yang terdapat di dalam tegakan (Mueller-Dombois \& Ellenberg 1974; Soerianegara \& Indrawan 1982). Analisis kesamaan komunitas habitat menggunakan Indeks Jaccard (Ludwig \& Reynolds 1988) dan divisualisasikan dengan dendrogram menggunakan program $R$, package: Vegan (version 3.5.2, R core team 2019). Analisis contoh tanah untuk mengetahui tingkat kesuburan tanah yang bersifat makro di dalam tegakan, yaitu $\mathrm{C} / \mathrm{N}$ ratio, bahan organik, $\mathrm{N}, \mathrm{P}, \mathrm{K}, \mathrm{Ca}$, dan $\mathrm{Mg}$, serta KTK tanah. Perbedaan kandungan unsur-unsur dalam tanah antar lokasi dianalisis menggunakan Chi-Square (McHugh 2013).

Penentuan status konservasi H. nymphaeifolia dilakukan dengan menggunakan kriteria kelangkaan IUCN (2019) dengan modifikasi cakupan untuk wilayah Indonesia. Pembatasan wilayah dilakukan karena ada indikasi populasi dan habitat yang terus menurun di Indonesia, serta ketersediaan data yang terbatas di wilayah ini saja. Informasi lokasi populasi atau tempat ditemukannya $H$. nymphaeifolia selain dari hasil penelitian ini, dilakukan dengan menggunakan data spesimen herbarium yang diakses melalui portal Global Biodiversity Information Facility/GBIF (GBIF.org 2020) dan portal Google Scholar (www.scholar.google.com) dengan menggunakan kata kunci Hernandia nymphaeifolia (termasuk sinonimnya $H$. peltata) dan pembatasan pada wilayah Indonesia saja. Penentuan luas Extent of Occurrence (EOO) dan Area of Occupancy (AOO) dilakukan dengan menggunakan aplikasi daring GeoCat (Bachman et al. 2011).

\section{HASIL DAN PEMBAHASAN}

\section{Distribusi}

Distribusi $H$. nymphaeifolia di Kalimantan ditemukan di seluruh bagian pulau yang memiliki pantai berpasir sebagai habitat alaminya, baik bagian timur, barat dan selatan. Hal ini sesuai dengan publikasi habitat $H$. nymphaeifolia di berbagai wilayah seperti Sarawak (Saw 2007), Ujung genteng (Kalima 2013), Bitung (Arini \& Kinho 2015), dan Parigi Mutong (Alfaida et al. 2013). Jenis ini juga hadir di Pulau Krakatau dan menjadi bagian dari 
proses suksesi ekosistem hutan pantai (Tukirin pers.comm.).

Dari 18 lokasi penelitian, H. nymphaeifolia hanya ditemukan di tujuh lokasi dengan jumlah individu bervariasi, mulai dari 1 hingga 13 pohon dewasa di setiap lokasi. Secara keseluruhan, hanya ditemukan 44 pohon dewasa di seluruh lokasi pengamatan. Sebaran, nama lokasi, dan jumlah individu secara lengkap dapat dilihat pada Tabel 2.

Tabel 2. Jumlah individu $H$. nymphaeifolia di tujuh lokasi penelitian di Kalimantan

\begin{tabular}{llccc}
\hline \multicolumn{1}{c}{ Provinsi } & \multicolumn{1}{c}{ Lokasi } & Semai & Pancang & Pohon \\
\hline $\begin{array}{l}\text { Kalimantan } \\
\text { Barat }\end{array}$ & Tanjung Batu & 2 & 1 & 8 \\
$\begin{array}{l}\text { Kalimantan } \\
\text { Selatan }\end{array}$ & $\begin{array}{l}\text { Muara Asam- } \\
\text { asam }\end{array}$ & 0 & 0 & $2^{1)}$ \\
$\begin{array}{l}\text { Kalimantan } \\
\text { Timur }\end{array}$ & Samboja & 0 & 0 & 13 \\
& $\begin{array}{l}\text { Muara Badak } \\
\text { Tanjung }\end{array}$ & 0 & 13 & 13 \\
& $\begin{array}{l}\text { Senipah } \\
\text { Kali Urang }\end{array}$ & 119 & 13 & 13 \\
& Biduk-Biduk & - & - & 5 \\
& 122 & 34 & 44 \\
\hline $\begin{array}{l}\text { Jumlah } \\
\text { 1) Tidak dibuat plot pengamatan }\end{array}$ \\
$\begin{array}{l}\text { 2) Data eksplorasi herbarium WAN } \\
\text { Sumber: Sitepu (2015), data primer }\end{array}$
\end{tabular}

Rendahnya populasi $H$. nymphaeifolia di Kalimantan diduga akibat pemanfaatan yang berlebihan maupun kematian yang tidak disertai dengan tumbuhnya permudaan alami. Informasi dari masyarakat di Tanjung Senipah, kayu $H$. nymphaefolia sering digunakan sebagai bahan baku papan untuk lantai pondok di kebun. Hasil penelusuran di Samboja hanya menemukan satu tegakan pohon tanpa ada permudaan sama sekali dan satu tegakan lainnya telah mati. Minimnya permudaan ini dapat disebabkan oleh ketidakmampuan semai dan pancang $H$. nymphaeifolia untuk bersaing dengan jenis lainnya untuk tumbuh sebagaimana ditemukan di Senipah dan Sekerat, Kalimantan Timur. Penyebab lainnya dapat juga karena ketiadaan permudaan akibat kegagalan biji berkembang menjadi semai sebagaimana yang terjadi di Tanjung Batu (Kalimantan Barat), Samboja (Kalimantan Timur), dan Muara Asam-asam (Kalimantan Selatan), walaupun di ketiga lokasi tersebut ditemukan pohon dewasa yang berbuah dan tidak ada vegetasi lain di sekitarnya. Diperlukan pengamatan lebih lanjut untuk mengetahui penyebab kegagalan perkecambahan biji $H$. nymphaeifolia di ketiga lokasi tersebut, maupun analisis kemampuan tegakan permudaan dalam bersaing dengan jenis lain sebagaimana temuan Zhang et al. (2017) perihal efek negatif alelopati serasah daun cemara (Casuarina equisetifolia) terhadap pertumbuhan semai jenis ini.

\section{Ekologi}

Hutan pantai berpasir merupakan habitat khas $H$. nymphaeifolia, dan pada semua lokasi penelitian habitat jenis ini ditemukan Pongamia pinnata, Hibiscus tiliaceus, Calophyllum inophyllum, Pouteria obovata, Excoecaria agallocha, Scaevola taccada, dan Terminalia catappa yang merupakan jenis-jenis yang umum ditemukan pada ekosistem hutan pantai (Turner et al. 2000; Mukhlisi \& Sidiyasa 2011; Alfaida et al. 2013). H. nymphaeifolia di Kalimantan cenderung tumbuh soliter atau dalam kelompok sangat kecil (kurang dari lima pohon pada jarak $100 \mathrm{~m}$ ), sehingga tidak pernah menjadi jenis dominan di habitatnya yang ditunjukkan dengan nilai INP yang rendah (Tabel 3). Di seluruh lokasi dimana $H$. nymphaeifolia ditemukan, Hibiscus tiliaceus dan Pongamia pinnata merupakan jenis yang dominan, dengan nilai INP yang tinggi. Selain itu, kedua jenis tersebut juga tumbuh mengelompok dan kadang membentuk gugusan memanjang di sepanjang pantai. Kondisi ini berbeda dibandingkan dengan hasil penelitian Kalima (2013) di Hutan Lindung Ujung Genteng (Jawa Barat) bagian barat, dimana $H$. nymphaeifolia menjadi jenis yang paling dominan dan di bagian timur menempati urutan kedua.

Indeks kesamaan komunitas antar habitat H. nymphaeifolia di Kalimantan tergolong rendah, ditunjukkan dengan nilai kesamaan komunitas di bawah 0,5 (Tabel 4) dan dendrogram (Gambar 2). Walaupun terdapat pada ekosistem yang sama, yaitu hutan pantai, namun keragaman vegetasi di masing-masing lokasi menunjukkan keragaman jenis tumbuhan penyusun yang berbeda di setiap lokasi. Namun kondisi tanah dan iklim mikro antara masing-masing lokasi habitat menunjukkan kemiripan (Tabel 5). 
Tabel 3. Lima jenis tumbuhan tingkat pohon dengan INP tertinggi di habitat H. nymphaeifolia di empat lokasi penelitian

\begin{tabular}{lllr}
\hline \multicolumn{1}{c}{ Lokasi } & No. & \multicolumn{1}{c}{ Nama jenis } & \multicolumn{1}{c}{$\begin{array}{c}\text { INP } \\
\text { (\%) }\end{array}$} \\
\hline Tanjung & 1 & Pongamia pinnata & 201,60 \\
Batu & 2 & Hernandia nymphaeifolia & 23,70 \\
& 3 & Terminalia catappa & 23,10 \\
& 4 & Thespesia populnea & 19,30 \\
Muara & 5 & Hibiscus tiliaceus & 10,50 \\
Badak & 1 & Pongamia pinnata & 56,89 \\
& 2 & Hibiscus tiliaceus & 55,88 \\
& 3 & Casuarina equisetifolia & 43,73 \\
& 4 & Pouteria obovata & 42,96 \\
Senipah & 5 & Hernandia nymphaeifolia & 34,00 \\
& 1 & Pongamia pinnata & 125,22 \\
& 2 & Hibiscus tilliaceus & 58,09 \\
& 3 & Hernandia nymphaeifolia & 35,72 \\
& 4 & Adenanthera & 20,78 \\
& 4 & kostermansii & \\
& 5 & Vitex pinnata & 19,18 \\
Kali Urang & 1 & Pongamia pinnata & 111,09 \\
& 2 & Hibiscus tiliaceus & 57,17 \\
& 3 & Terminalia catappa & 44,65 \\
& 4 & Ficus sp. & 21,83 \\
& 5 & Hernandia nymphaeifolia & 20,66 \\
\hline Sumber: Sitepu (2015) & data primer &
\end{tabular}

Sumber: Sitepu (2015), data primer

Tabel 4. Indeks kesamaan komunitas antar empat habitat $H$. nymphaeifolia di Kalimantan

\begin{tabular}{|c|c|c|c|c|}
\hline & KU & TB & $\mathrm{MB}$ & TS \\
\hline $\mathrm{KU}$ & 0 & 0.36 & 0.32 & 0.28 \\
\hline TB & & 0 & 0.25 & 0.33 \\
\hline $\mathrm{MB}$ & & & 0 & 0.17 \\
\hline TS & & & & 0 \\
\hline
\end{tabular}

Sumber: Sitepu (2015), data primer

KU: Kali Urang, MB: Muara Badak, TS: Tanjung Senipah,

TB: Tanjung Batu

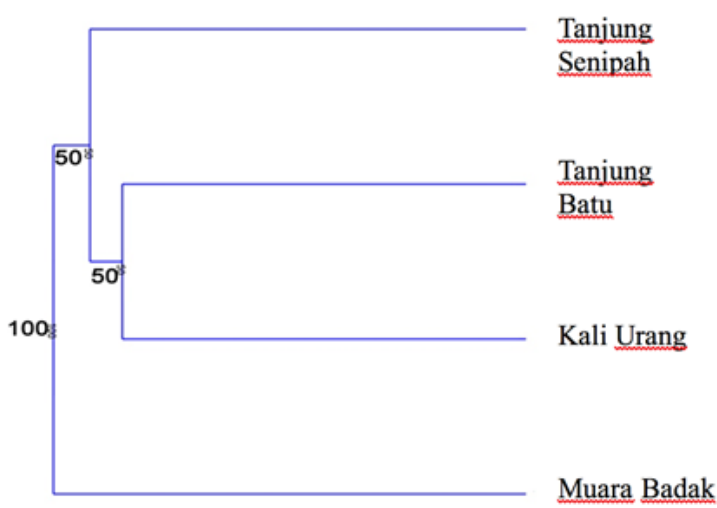

Gambar 2. Dendrogram kemiripan vegetasi penyusun habitat $H$. nymphaeifolia di empat lokasi penelitian di Kalimantan (Jaccard indeks, Cophen. corr. $=0,6725$ )

Berdasarkan analisis statistik, umumnya kondisi fisik tanah, iklim mikro, dan kimia tanah tidak menunjukkan perbedaan yang signifikan, kecuali persentase kandungan pasirnya yang berbeda sangat nyata antar lokasi $\left(X^{2}=89,46\right.$; $\mathrm{p}=0.000$ ) (Tabel 5). Secara umum, H. nymphaeifolia menempati tapak tanah berpasir dominan atau lempung berpasir dengan persentase komponen pasir 160-350\% dengan KTK rendah, dan keasaman sedang hingga rendah (Tabel 5). Kandungan $\mathrm{C} / \mathrm{N}$ ratio tergolong sedang dengan nilai $13,6-15,6 \%$, menunjukkan proses dekomposisi bahan organik lebih lambat. Temuan di lapangan dan spesimen herbarium menunjukkan jenis ini sangat spesifik tumbuh pada pantai berpasir, khususnya pada formasi Barringtonia asiatica (Hoogerwerf 1970; Supriatna 2014) dan tidak pernah ditemukan pada areal mangrove berlumpur.

Tabel 5. Kondisi fisik, iklim mikro, dan kimia tanah pada habitat $H$. nymphaeifolia di setiap provinsi

\begin{tabular}{|c|c|c|c|c|c|c|c|}
\hline \multirow{2}{*}{ No. } & \multirow{2}{*}{ Parameter } & \multicolumn{4}{|c|}{ Lokasi } & \multirow{2}{*}{$\mathbf{p}$} & \multirow{2}{*}{$x^{2}$} \\
\hline & & KALTIM & KALBAR & KALTENG & KALSEL & & \\
\hline 1. & Silk (\%) & 15,63 & 10,20 & 19,00 & 10,60 & 0,276 & $3,90^{\text {ns }}$ \\
\hline 2. & Clay (\%) & 18,50 & 14,90 & 24,90 & 27,80 & 0,185 & $5,31^{\text {ns }}$ \\
\hline 3. & Total sand (\%) & 215,88 & 174,90 & 356,10 & 161,60 & 0,000 & $89,46^{1)}$ \\
\hline 4. & Tekstur (Segitiga tekstur) & Sand, $\mathrm{SL}^{2)}, \mathrm{LS}^{3)}, \mathrm{SCL}^{4}$ & Sand, SL & Sand, LS, SL & Sand, SCL & & \\
\hline 5. & Kelembaban (\%) & 64,48 & 65,60 & 70,00 & 65,00 & 0,962 & $0,28^{5)}$ \\
\hline 6. & Suhu $\left({ }^{\circ} \mathrm{C}\right)$ & 31,14 & 29,96 & 32,56 & 31,94 & 0,989 & $0,12^{5)}$ \\
\hline 7. & Keasaman $(\mathrm{pH})$ & 6,10 & 6,60 & 6,43 & 6,30 & 0,999 & $0,02^{5)}$ \\
\hline 8. & Kation Basa (NH4 -OAC): & & & & & 0,615 & $4,11^{5)}$ \\
\hline & $\mathrm{Ca}++(\mathrm{me} / 100 \mathrm{~g})$ & 2,235 & 0,57 & 3,23 & 1,99 & 0,999 & $0,03^{5)}$ \\
\hline & $\mathrm{Mg}++(\mathrm{me} / 100 \mathrm{~g})$ & 0,92 & 0,78 & 0,72 & 0,78 & 0,350 & $7,21^{5)}$ \\
\hline & $\mathrm{Na}+(\mathrm{me} / 100 \mathrm{~g})$ & 1,55 & 0,86 & 3,18 & 0,25 & 0,996 & $0,08^{5)}$ \\
\hline
\end{tabular}




\begin{tabular}{|c|c|c|c|c|c|c|}
\hline \multirow{2}{*}{ Parameter } & \multicolumn{4}{|c|}{ Lokasi } & \multirow{2}{*}{$\mathbf{p}$} & \multirow{2}{*}{$x^{2}$} \\
\hline & KALTIM & KALBAR & KALTENG & KALSEL & & \\
\hline d. $\mathrm{K}+(\mathrm{me} / 100 \mathrm{~g})$ & 0,25 & 0,17 & 0,22 & 0,11 & 0,482 & $2,40^{5)}$ \\
\hline 9. KTK (me/100g) & 5,49 & 3,67 & 7,79 & 3,35 & 0,954 & $0,28^{5)}$ \\
\hline 11. N. Total (\%) & 0,35 & 0,09 & 0,11 & 0,07 & 0,995 & $0,07^{5)}$ \\
\hline 12. C. Organik (\%) & 1,26 & 1,46 & 1,39 & 1,07 & 0,979 & $0,20^{5}$ \\
\hline 13. Ratio C/N (\%) & 15,66 & 15,61 & 13,61 & 14,61 & 0,962 & $\left.0,28^{5}\right)$ \\
\hline
\end{tabular}

1) Berbeda Nyata $(\alpha=0,01)$

2) $S L=$ Sand Loam (Pasir berlempung)

3) $L S=$ Loam Sand (Lempung berpasir)

4) $\mathrm{SCL}=$ Sand Clay Loam (Pasir Liat Berlempung)

5) Tidak berbeda nyata

Sumber: Sitepu (2015), data primer

\section{Status konservasi}

Hernandia nymphaeifolia memiliki sebaran yang luas di Indonesia, mencakup dari ujung Aceh di Pulau We, hingga Papua dan Kepulauan Aru. Berdasarkan hasil penelusuran di GBIF dan Google Scholar ditemukan 77 lokasi, sehingga di Indonesia jenis ini total ditemukan di 84 lokasi. Catatan temuan di Kalimantan ini merupakan yang pertama terdiseminasi. Sebelumnya, sebagian besar eksplorasi dilakukan di Jawa, Sulawesi, dan Kepulauan Maluku. Hasil perhitungan dengan aplikasi GeoCat menunjukkan luas EOO sebesar $4.527 .365 \mathrm{~km}^{2}$ dan AOO seluas $69 \mathrm{~km}^{2}$. Berdasarkan hasil penelitian Sitepu (2015) dan Kalima (2013), kepadatan pohon dewasa $H$. nymphaefolia sangat bervariasi mulai dari 135 pohon/ha hingga kurang dari 10 pohon/ha. Khusus di Kalimantan, pada satu lokasi habitat tidak ditemukan pohon dewasa lebih dari 13 pohon (Tabel 2).

Hasil pengamatan di lapangan dan gambar satelit yang diakses melalui aplikasi Google Earth Pro ver. 7.3.3.7699 (Google LCC 2019). menunjukkan beberapa lokasi habitat $H$. nymphaeifolia, khususnya informasi dari spesimen herbarium dari sebelum tahun 1970an, telah berubah menjadi areal permukiman dan wisata (Ambon, Manado, Tanjung Priok), tambak dan kebun kelapa (Sukahudjan, Pekalongan, Halmahera). Hal ini sesuai dengan temuan di Kalimantan dimana ancaman terhadap pemanfaatan pohon dewasa serta alih fungsi lahan sebagai kawasan pemukiman, perkebunan, serta pariwisata diketahui sangat tinggi. Habitat H. nymphaeifolia di Kalimantan Barat dan Kalimantan Selatan telah menjadi areal wisata dan mengalami perubahan rona ekosistem. Hal ini ditunjukkan dengan kepadatan vegetasi penyusun dan jumlah jenis yang ada di setiap habitat. Habitat di Kalimantan Timur, kecuali di Samboja, lebih terjaga yang ditunjukkan dengan keragaman dan kepadatan vegetasi penyusun habitat H. nymphaeifolia. Namun, di Tanjung Senipah, perkebunan kelapa sawit sudah mengambil sebagian habitat $H$. nymphaeifolia, khususnya di bagian belakang garis pantai yang tidak terpengaruh pasang surut air laut. Walaupun memiliki ekosistem pantai berpasir, Kalimantan Tengah yang memiliki pantai terpanjang di Kalimantan, sama sekali tidak ditemukan jenis ini. Diperkirakan ketiadaannya akibat pemanfaatan untuk kayu di masa lampau dan perubahan ekosistem yang telah menjadi kawasan wisata dan pemukiman.

Berdasarkan kondisi aktual di lapangan dengan luasan AOO kurang dari $500 \mathrm{~km}^{2}$, adanya kecenderungan dan ancaman terhadap kerusakan habitat jenis target, dan jumlah pohon dewasa yang sangat berfluktuasi di seluruh lokasi temuan, maka H. nympahefolia untuk wilayah Indonesia memiliki status konservasi Genting (Endangered) dengan kriteria B2b(ii,iii)c(ii,iii). Status kelangkaan $H$. nymlphaefolia yang termasuk Genting (Endangered) dapat digunakan sebagai dasar pengelolaan jenis ini, khususnya dalam upaya perlindungan dan pelestariannya. Penilaian status konservasi dalam skala nasional dan global juga perlu dilakukan untuk memberikan informasi kelangkaan jenis ini akibat proses alami maupun akibat kegiatan manusia.

Teknologi konservasi $H$. nymphaeifolia baik secara in situ maupun ex situ saat ini belum tereksplorasi dengan baik. Namun, di bidang farmakologi jenis ini telah cukup mapan dipelajari dan diketahui mengandung berbagai senyawa kimia 
yang berpotensi sebagai bahan baku obat ( $G u$ \& Kinghorn 2005; Suthiwong et al. 2018), bahkan urutan lengkap genome kloroplasnya telah teridentifikasi (Zhang et al. 2018). Potensi ini merupakan peluang pengembangan H. nymphaefolia, baik untuk kepentingan pelestarian maupun pemanfaatan bukan kayu oleh masyarakat. Penelitian mengenai teknologi perkecambahan dan penyemaian, pertumbuhan semai di pembibitan dan percobaan penanaman di lapangan, hingga aktivitas reproduksi dan regenerasi secara alami di habitatnya merupakan kegiatan yang mendesak untuk dilakukan sebagai bagian dari upaya konservasinya di Kalimantan.

\section{KESIMPULAN DAN SARAN}

Hernandia nymphaeifolia tersebar di beberapa pulau di Indonesia, namun di Kalimantan jenis ini memiliki populasi dan kepadatan yang sangat rendah. Secara regional (untuk wilayah Kalimantan), jenis ini dapat dikategorikan ke dalam status konservasi Genting (EN B2b (ii,iii)c(ii,iii)).

Upaya konservasi secara terpadu dapat dilakukan melalui penggunaan perangkat hukum dalam skala daerah maupun regional, pelaksanaan penelitian dalam bidang terkait, serta pelibatan masyarakat sebagai pelaku pelestarian dan pengambil manfaat dalam jangka panjang. Penelitian lebih lanjut terkait upaya perbanyakan $H$. nymphaeifolia perlu dilakukan terkait minimnya kemampuan regenerasi jenis ini di alam. Selain itu, upaya inventarisasi dan penelitian jenis ini di pulaupulau kecil di sekitar Kalimantan juga penting untuk dilakukan agar informasi populasi dari jenis ini dapat terus diperbaharui.

\section{UCAPAN TERIMA KASIH}

Terima kasih diucapkan kepada Tim Peneliti Habitat dan Populasi Ki Beusi dan Kampis di Kalimantan: Dr. Kade Sidiyasa (RIP), Zainal Arifin, Mardi Tofani Rengku, Iman Suharja, Ermansyah, dan Fitra Al-Hani. Ucapan terima kasih juga disampaikan kepada Prof. Dr. Tukirin Partomihardjo dan Titi Kalima, M.Si. untuk tambahan informasi yang memperkaya tulisan ini. Penelitian ini didanai oleh dana APBN tahun 2012-2016.

\section{DAFTAR PUSTAKA}

Aimaiti S, Saito Y, Fukuyoshi S, Goto M, Miyake K, Newman DJ, O'Keefe BR, Lee KH, NakagawaGoto K. 2019. Isolation, structure elucidation, and antiproliferative activity of butanolides and lignan glycosides from the fruit of Hernandia nymphaeifolia. Molecules 24(21): 4005. https://doi.org/10.3390/ molecules24214005 (diakses 12 Oktober 2019).

Alfaida, Samsurizal MS, Musdalifah N. 2013. Jenisjenis tumbuhan pantai di Desa Pelawa Baru, Kecamatan Parigi Tengah, Kabupaten Parigi Moutong dan pemanfaatannya sebagai buku saku. E-Jurnal IImiah Pendidikan Biologi 1: 19-32 (diakses 12 Oktober 2019).

Arini DID, Kinho J. 2015. Keragaman tumbuhan berkhasiat obat di hutan pantai Cagar Alam Tangkoro. Jurnal Wasian 2(1): 1-8. https://doi.org/10.20886/jwas.v2i1.863 (diakses 19 Oktober 2019).

Bachman S, Moat J, Hill AW, de la Torre J, Scott B. 2011. Supporting Red List threat assessments with GeoCAT: geospatial conservation assessment tool. In: Smith $\mathrm{V}$, Penev L (eds) e-Infrastructures for data publishing in biodiversity science. ZooKeys 150: 117-126. (Version BETA)*

Das S, Mukherjee H, Ahmed SM, Haldar PK, Mandal AB, Mahapatra A, Chattopadhyay D. 2013. Evaluation of an ethnomedicinal combination containing Semecarpus kurzii and Hernandia peltata used for the management of inflammation. Pharmaceutical Biology 51(6): 677-685. https//doi.or/10.3109/ 13880209.2012.762405 (diakses 12 Oktober 2019).

Duyfjes BEE. 1993 Hernandiaceae. In: Kubitzki K, Rohwer JG, Bittrich V (eds.). Families and genera of vascular plants Vol. 2. Springer, Berlin.

Duyfjes BEE. 1996. Hernandiaceae. In: Kalkman C, Kirkup DW, Nooteboom HP, Stevens PF, de Wilde WJJO (eds.). Flora Malesiana series 1(12). Flora Malesiana Foundation, Leiden, Netherlands.

Dittmar A. 1991. The effectiveness of Hernandia species (Hernandiaceae) in traditional Samoan medicine and accordining to 
scientific analysis. Journal Ethnopharmacy. 33: 243-251. https://doi.org/10.1016/03788741(91) 90084-Q (diakses 12 Oktober 2019).

Elzinga CL, Salzer DW, Willoughby, JW. 1998. Measuring and monitoring plant populations. US Department of the Interior, Bureau of Land Management. Denver.

ESRI. 2012. ArcGIS Ver.10.1. for Window. http://desktop.arcgis.com. Redlands, CA. USA.

GBIF.org. 2020. GBIF Home Page. https://www.gbif.org (13 January 2020).

Giri C, Long J, Abbas S, Murali RM, Qamer FM, Pengra B, Thau D. 2015. Distribution and dynamics of mangrove forests of South Asia. Journal of environmental management 148: 101-11. https://doi.org/10.1016/j.jenvman. 2014.01.020 (diakses 21 April 2020).

Google LCC. 2019. Google Earth Pro Ver. 7.3.3.7699. http://www.google.com/earth. (diakses Oktober-November 2019).

Gu JQ, Kinghorn AD. 2005. Bioactive constituents of the genus Hernandia. Studies in Natural Products Chemistry 30: 559-602. https://doi.org/10.1016/S15725995(05)80042-0 (diakses 12 Oktober 2019).

Heyne K. 1987. Tumbuhan berguna indonesia Vol. II: 828-829. Badan Litbang Kehutanan, Jakarta.

Hoogerwerf A. 1970. Udjung Kulon: the land of the last Javan rhinoceros. E.J. Brill, Leiden.

Irwanto RRP. 1998. Hernandia nymphaeifolia (Presl) Kubitzki. In: Sosef MSM, Hong LT, Prawirohatmodjo S. (eds.): Plant Resources of South-East Asia No 5(3): Timber trees: Lesser-known timbers. PROSEA Foundation, Bogor.

IUCN Standards and Petitions Committee. 2019. Guidelines for using the IUCN red list categories and criteria (version 14). Prepared by the Standards and Petitions Committee.

https://www.iucnredlist.org/resources/redli stguidelines (diakses: 14 June 2019).

Jonah FE, Boateng I, Osman A, Shimba MJ, Mensah EA, Adu-Boahen K, Chuku EO, Effah E. 2016. Shoreline change analysis using end point rate and net shoreline movement statistics: An application to Elmina, Cape Coast and
Moree section of Ghana's coast. Regional Studies in Marine Science 7: 19-31.

Kalima T. 2013. Populasi dan habitat kampis (Hernandia nymphaeifolia (C. Presl) Kubitzki) di Hutan Lindung Ujung Genteng. Jurnal Penelitian Hutan dan Konservasi Alam 10(1): 63-79. https://doi.org/10.20886/jphka. 2013.10.1.63-79 (diakses 12 Oktober 2019).

Lakshmi V, Pandey K, Mishra S, Srivastava S, Mishra M, Agarwal S. 2009. An Overview of family Hernandiaceae. Records of Natural Products 3(1): 1-22. (diakses 12 Oktober 2019).

Ludwig JA, Reynolds JF. 1988. Statistical ecology: a primer in methods and computing. John Wiley \& Sons, New York.

McHugh ML. 2013. Lessons in biostatistics the chisquare test of independence. Biochemia Medica 23(2): 143-149. https://doi.org/ 10.11613/bm.2013.018 (diakses 12 Oktober 2019).

Michalak I, Zhang LB, Renner SS. 2010. TransAtlantic, trans-Pacific and trans-Indian Ocean dispersal in the small Gondwanan Laurales family Hernandiaceae. Journal of Biogeography 37(7): 1214-1226. https://doi. org/10.1111/j.1365-2699.2010.02306.x (diakses 21 April 2020).

Mukhlisi, Sidiyasa K. 2011. Aspek ekologi nyamplung (Calophyllum inophyllum L.) di hutan Pantai Tanah Merah, Taman Hutan Raya Bukit Soeharto. Jurnal Penelitian Hutan dan Konservasi Alam 8(4): 385-397. http://dx.doi.org/10.20886/jphka.2011.8.4. 385-397 (diakses 12 Oktober 2019).

Mueller-Dombois D, Ellenberg D. 1974. Aims and methods of vegetation ecology. Wiley, New York.

Pinto Z. 2015. Kajian perilaku masyarakat pesisir yang mengakibatkan kerusakan lingkungan (studi kasus di Pantai Kuwaru, Desa Poncosari, Kecamatan Srandakan, Kabupaten Bantul, Provinsi Daerah Istimewa Yogyakarta). Jurnal Wilayah dan Lingkungan 3(3): 163-174. http://dx.doi.org/10.14710/ jwl.3.3.163-174 (diakses 21 April 2020).

Prihantono J, Fajrianto IA, Kurniadi YN. 2018. Pemodelan hidrodinamika dan transpor sedimen di perairan pesisir sekitar Tanjung Pontang, Kabupaten Serang, Banten. Jurnal Kelautan Nasional 13(2): 75-88. 
http://dx.doi.org/10.15578/jkn.v1i2.6614

(diakses 21 April 2020).

POWO. 2019. Plants of the world online. Facilitated by the Royal Botanic Gardens, Kew. Published on the Internet: http://powo. science.kew.org/taxon/urn:Isid:ipni.org:na mes:430812-1 (diakses 13 April 2020).

R Core Team. 2019. R: A language and environment for statistical computing. R Foundation for Statistical Computing, Vienna, Austria. (https://www.R-project.org/).

Sitepu BS. 2015. Hernandia nymphaeifolia di Kalimantan (habitat, penyebaran dan populasi). Swara Samboja IV(3): 14-20.

Saw LG. 2007. Hernandiaceae. In: Soepadmo E, Saw LG, Chung RCK, Kiew R. (eds). Tree Flora of Sabah and Sarawak. Volume 6. Forest Research Institute Malaysia,Sabah Forestry Department \& Sarawak Forestry Department, Malaysia.

Soerianegara I, Indrawan A. 1982. Ekologi hutan Indonesia. Departemen Manajemen Hutan Fakultas Kehutanan IPB, Bogor

Supriatna J. 2014. Berwisata di Taman Nasional. Yayasan Pustaka Obor Indonesia, Jakarta.

Susilo. 2017. Analisis vegetasi mangrove (Rhizophora) di pesisir pantai Pulau Menjangan Besar Karimunjawa. Biomedika 10(2): 58-68. https://doi.org/10.31001/ biomedika.v10i2.276 (diakses 12 April 2020).

Suyarso S, Prayudha B, Iswari MY. 2018. Mangroves adaptation to changes of environment: Case study on Nias Earthquake, North Sumatra, March 2005. Oseanologi dan Limnologi di Indonesia 3(2): 155-64. https://doi.org/ 10.14203/oldi.2018.v3i2.136 (diakses 21 April 2020).

Suthiwong J, Boonloh K, Kukongviriyapan V, Yenjai C. 2018. Cytotoxicity against cholangiocarcinoma and HepG2 cell lines of lignans from Hernandia nymphaeifolia. Natural Product Communications 13(1): 61-63. https://doi.org/10.1177/1934578X1801300 118 (diakses 12 Otober 2019).

Tuheteru FD, Mahfudz. 2012. Ekologi, manfaat, dan rehabilitasi hutan pantai Indonesia. Balai Penelitian Kehutanan, Manado.

Turner IM, Xing F, Corlett RT. 2000. An annotated check-list of the vascular plants of the South
China Sea and its shores. Raffles Bulletin Zoology. Suplement No. 8: 23-116

Wei CY, Wang SW, Ye JW, Hwang TL, Cheng MJ, Sung PJ, Chang TH, Chen JJ. 2018. New antiinflammatory aporphine and lignan derivatives from the root wood of Hernandia nymphaeifolia. Molecules 23 (9): 2286. https://doi.org/10.3390/molecules2309228 6. (diakses 12 Oktober 2019).

Zhang Y, Guan W, Tang MN, Li YH, Li L. 2017. Effects of Casuarina equisetifolia L. leachate on photosynthesis and antioxidant enzymes in seedlings of Hernandia nymphaeifolia (C. Presl) Kubitzki. Allelopathy Journal 40: 209224.

Zhang Y, Zhang JW, Jin YH, Li DL, Diao XP. 2018. Complete chloroplast genome of an endangered mangrove plant Hernandia nymphaeifolia (C. Presl) Kubitzki (Hernandiaceae), Mitochondrial DNA Part B, 3(1): 231-232. https://doi.org/10.1080/ 23802359.2018.1437830 (diakses 20 April 2020).

Zhong CR, Li SC, Guan W, Li H, Lin XY, Liao BW. 2011. Current distributions of three endangered mangrove species in China. Ecological Science. 30: 431-435. doi:10.3969/j.issn. 1008-8873.2011.04. 011 (diakses 12 Oktober 2019) (dalam bahasa Tiongkok). 